\title{
Determination Contents of Total Phenolic Pigments and Spectrophotometric Characterization of Crude Extracts of Ten Tinctorial Plants of Niger which is Usable in Solar Energy
}

\author{
Souley Kallo Moutari \\ Ayouba Mahamane Abdoulkadri \\ Abdourahamane Saidou Boulhassane \\ Adamou Rabani
}

Université Abdou Moumouni, Faculté des Sciences et Techniques, Département de Chimie, Laboratoire Matériaux, Eaux et Environnement

(LAMEE), Groupe de Recherche Physico-chimie des Matériaux et

Photochimie Appliquée, Niamey, Niger

Ikhiri Khalid

Université Abdou Moumouni, Faculté des Sciences et Techniques,

Département de Chimie, Laboratoire des Substances Naturelles et Synthèse

Organique (LASNASO), Niamey, Niger

Doi: 10.19044/esj.2018.v14n33p389 URL:http://dx.doi.org/10.19044/esj.2018.v14n33p389

\begin{abstract}
Dye Sensitized-Solar Cells (DSSCs) have been extensively investigated because of their environmental friendliness and low production cost. At the heart of these is the photosensitive pigment that plays a key role in the collection of sunlight radiations and its conversion into electrical energy. However, the toxicity and the cost of pigment synthesis limit the increased use of these prototypes. Natural pigments can be an effective, sustainable, and inexpensive alternative. This paper focuses on determining the main phenolic pigments contents and evaluating the solar light collection capacity of ten (10) tinctorial plants crude extracts, via UV-Visible Spectrophotometry. High concentrations of total polyphenols (46.54 $\mathrm{mgEqAG} / \mathrm{g})$, flavonoids (10.95 mgEqQuer/g), anthocyanins $\left(181.9 \mathrm{mgL}^{-1}\right)$, and tannins $\left(40.1 \mathrm{mgL}^{-1}\right)$ were recorded in some extracts of these plants. Absorption spectra showed intense absorption domains around $280 \mathrm{~nm}$ in the ultraviolet (UV), and also in the visible (400 to $700 \mathrm{~nm}$ ). These absorptions would be attributed to the $\pi-\pi^{*}$ and $n-\pi^{*}$ electron transitions of the chromophores present in the anthocyanin, flavonoid, carotenoid, and chlorophyll pigments of these plants. The high contents of pigments and the
\end{abstract}


appropriate spectrophotochemical properties make the extracts of these tinctorial plants to become potential raw materials that are useful in solar energy technology.

Keywords: Tinctorial plants, polyphenolic pigments, sunlight collection, Niger

\section{Introduction}

Growing energy needs, the depletion of fossil fuel reserves, the risk of accidents and nuclear waste, atmospheric pollution, global warming, and climate hazards are increasingly calling for the use of renewable energies (biomass, wind turbines, geothermal, hydraulic and solar) (Asim et al., 2012a). Of all the renewable energies, solar energy seems to be the most abundant and the most accessible. Chemists have long been interested in the idea of harnessing solar energy to conduct chemical reactions and/or to convert it into electricity (Kalyanasundaram, 2010). Indeed, the crucial role of solar radiation in the mechanism of photosynthesis and in the transformation of certain living molecules is well known (Blankenship, 2008; Rabinowitch et al., 2013). In the early 20th century, in 1912, at the International Congress of Applied Chemistry, Giacomo Ciamician, Professor of Chemistry at the University of Bologna (Italy), for the first time announced the idea of replacing fossil fuels by natural solar radiations (Kalyanasundaram, 2010). However, it took more than forty years for the first technology based on the collection and conversion of solar radiations to electricity to be proposed through a photovoltaic cell (Abrams, 2005; Kalyanasundaram, 2010). The principle of photovoltaic technology is based on the absorption of photons of high energy ultraviolet (UV) radiations and the generation of electrons by charge separation at the interface of two semiconductor materials having different conduction mechanisms. The first photovoltaic cell, with a conversion efficiency yield of 6\%, was manufactured in 1956 at the Bell Labs, USA (Abrams, 2005). It is based on the use of pure silicon single crystal, which is a very expensive material for large scale production of the prototype. The development of polycrystalline silicon (poly-Si) and gallium compounds (GaAs, InGaP) thin layer have increased the photovoltaic cell efficiency to $10 \%$. These materials allowed the first photovoltaic cell in the 60s (Abrams, 2005; Kalyanasundaram, 2010). Therefore, it was the highest cost of first generation cells based on mono-crystal silicon $(1 \mathrm{G}), 70 \%$ of manufacturing costs which led researchers to use less expensive materials with polycrystalline structure. Here, further investigations allowed the development of new materials to boost silicon cells conversion efficiency to over $20 \%$. From very expensive $1 \mathrm{G}$ Cells, researcher passed to $2 \mathrm{G}$ cells which are difficult to manufacture on a large scale, and finally to $3 \mathrm{G}$ cells based on relatively cheap and abundant 
materials (Grätzel, 2003; Kalyanasundaram, 2010). However, the solar panels manufacturing costs remain high enough to promote a worldwide development of the sector (Kalyanasundaram, 2010). For this reason, in 2015, the transformed solar energy contributes only $0.6 \%$ of the world global energy demand. Similarly, in developing countries in general, and in African countries in particular, despite the great availability of the resource, the contribution of solar energy remains derisory. Thus, the efficient low cost and easy to manufacture solar cell development challenge remains.

In this context, Michael Grätzel and Brian O'Regan suggested in 1991, in Nature, a credible revolutionary alternative simulating the solar radiations energy transformation mechanism by chlorophyll of plants (photosynthesis). For more than twenty (20) years, the dye sensitized solar cells called Grätzel cells are considered as a future photovoltaic device. Their benefits lie mainly in low-cost production, low investment recovery time, and flexibility in adapting to all surfaces (O'Regan \& Grätzel, 1991; Hug et al., 2014). Moreover, unlike solar cells in the form of semiconductor-based photovoltaic panels (PVs) which mainly absorb in the ultraviolet range, solar cells with photosensitive pigments can collect light in the visible and in the infrared. Indeed, the solar spectrum is composed of 52\% infrared, $43 \%$ visible, and $5 \%$ ultraviolet (UV) (Grätzel, 2003; Grätzel, 2004; Kalyanasundaram, 2010). The pigments generally used are organometallic complexes of ruthenium, cobalt such as N719, N3, black dye. The conversion efficiency obtained is of the order of 10 to $11 \%$ (Mehmood et al., 2014). However, the rarity of certain transition metals such as the element $(\mathrm{Ru})$, the potential latent risks due to the use of heavy metals, and the relatively high cost of pigment synthesis further limit the increased development of this prototype. For this reason, beyond synthetic organic pigments, natural pigments are a first choice alternative and their use is part of a sustainable development approach. Indeed, natural pigments are free of metals; they are non-toxic, non-carcinogenic, widely accessible, available at very low cost, and are biodegradable naturally without any other form of pollution (Siva, 2007; Harouna et al., 2012; Mabika et al., 2013). In addition, once in the dye-sensitized solar cell, the latter could promote a greater injection of electrons in the conduction band of semiconductors at an ultra-fast speed when excited with visible light. In addition, they possess sufficient hydroxyl groups to bind to the nanostructure of the semiconductor and good efficiency in collecting a large portion of solar radiation (Yamazaki et al., 2007; Asim et al., 2012a). All these properties make them good candidates for dye-sensitized solar cells (DSSC). Numerous studies on cells sensitized with natural pigments have been carried out, and appreciable conversion yields have been obtained. Calogero et al. (2012) showed that cells sensitized with natural anthocyanins and betalaines provided conversion efficiency of $2.06 \%$. In addition, a maximum conversion of $2.87 \%$ 
was obtained with Kenaf Hibiscus pigment (Saha et al., 2016). In Niger and even in the sub-region, there is lack of studies on the use of natural dyes in solar energy. Thus, important investigations need to be done in this scientific and technological field. The present study proposes to determine the contents of the main polyphenolic pigments and to evaluate through uv-visibe spectrophotometry their solar energy collection potentials. This is an initiative investigation to promote Niger and sub-region dye plants valorization in solar energy research and application.

\section{Material and Methods}

\section{Plant Material}

The plant material consisted of various plant parts (bark, roots, leaves, sheaths,) that have been freshly harvested and identified in the Department of Biology of the Faculty of Sciences and Technology Abdou Moumouni University in Niamey. These were ten species of plants that include the trunk bark of Lannea microcarpa Engl. and K. Krause (Anacardiaceae), Sclerocarya birrea (A. Rich) Hochst (Anacardiaceae), Khaya senegalensis (Desv.) A. Juss (Meliaceae), Detarium microcarpum Guill. and Perr. (Caesalpiniaceae), Parkia biglobosa (Jacq.) Benth (Mimosaceae), leaves of Anogeissus leiocarpus (DC.) Guill. and Perr. (Combretaceae) and Sorghum spp (Poaceae), aerial parts of Striga hermontheca (Del.) Benth (Scrofulariaceae) and roots of Sarcocephalus latifolia (Sm.) Bruce and Cochlospermum planchonii hook (Cochlospermaceae). Specimens were deposited in the herbarium of the department of biology of Abdou Moumouni University. These plant samples were first washed, dried under laboratory conditions, and was pulverized as a powder which was used to perform the various extractions.

\section{Chemicals and Instrumentation Chemical and Solvents}

Absolute ethanol, acetone, and methanol (sigma Aldrich) were used for the extraction of the pigments from the plant materials and / or as recovery solvents for the spectrophotometric characterization. In addition, sodium hydroxide solutions, $1 \mathrm{M}$ hydrochloric acid, and $1 \mathrm{M}$ (sigma Aldrich) were used to study the $\mathrm{pH}$ influence on the absorption of pigments in the UV and visible range. Phosphotungstic $\left(\mathrm{H}_{3} \mathrm{PW}_{12} \mathrm{O}_{40}\right)$ and phosphomolybdic $\left(\mathrm{H}_{3} \mathrm{PMo}_{12} \mathrm{O}_{40}\right)$ acids (used for the preparation of Folin-Ciocalteu reagent) and Sodium carbonate $\left(\mathrm{Na}_{2} \mathrm{CO}_{3}\right)$ were used in determination of total polyphenols. Also, Gallic acid $\left(\mathrm{C}_{7} \mathrm{H}_{6} \mathrm{O}_{5}\right)$ was used for calibration curve. Aluminum trichloride $\mathrm{AlCl}_{3}$ (sigma Aldrich) and quercetin $\mathrm{C}_{15} \mathrm{H}_{10} \mathrm{O}_{7}$ (sigma Aldrich) was used for the total flavonoids determination. All of these solvents and reagents were analytical grade and were used without further purification or modification. 


\section{Instrumentation}

The instruments used to conduct the research activities are: An oven to dry at $50^{\circ} \mathrm{C}$ some of our fresh samples. Additionally, a manual grinder for spraying in the form of fine powders was used. Subsequently, hydrophilic cotton and Wattman papers $\mathrm{N}^{\circ} 1$ served as filters and a Rotavapor (R-III Buchi) to concentrate the extracts and a sand bath for evaporating of solvents were also used. The extracts obtained were then characterized by UV-Vis spectrophotometry with a spectrophotometer Evolution $300 \mathrm{UV}$-Vis.

\section{Preparation of Dye Crude Powders Extracts}

The aqueous and hydro ethanolic extracts were respectively prepared by decoction and maceration (at room temperature). The aqueous extract was prepared according to the method described by Millogo-Kone et al. (2008). This operation was repeated 3 times in order to allow maximum extraction of the dye compounds present in the bark samples of Parkia biglobosa, Detarium microcarpum, Sclerocarya birrea, Khaya senegalensis, Lannea microcarpa and the aerial part of Striga hermontheca. Since the residues obtained after decoction of these samples remained always tinted, a $70 \%$ acetone treatment was performed to further extract the dyes (Figure 1). The hydro-ethanolic extract was prepared according to the method described by Millogo-Kone et al. (2008) by maceration with magnetic stirring in water-ethanol mixture (30: $70 \mathrm{~V} / \mathrm{V}$ ) for 24 hours (repeated 3 times). This technique gave the dye stuff aspect more perceptibility by hydro-ethanol maceration, which concerns Anogeissus leiocarpus, Sarcocephalus latifolia, Sorghum spp and Cochlospermum planchonii species (Figure 1). After filtration, the solvent was removed and crude powders extracts were obtained. 


\section{Powdered plant simples}

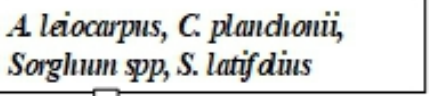

water' ethanol ( $3: 7 \mathrm{v} / \mathrm{v})$

Maceration, 3 times

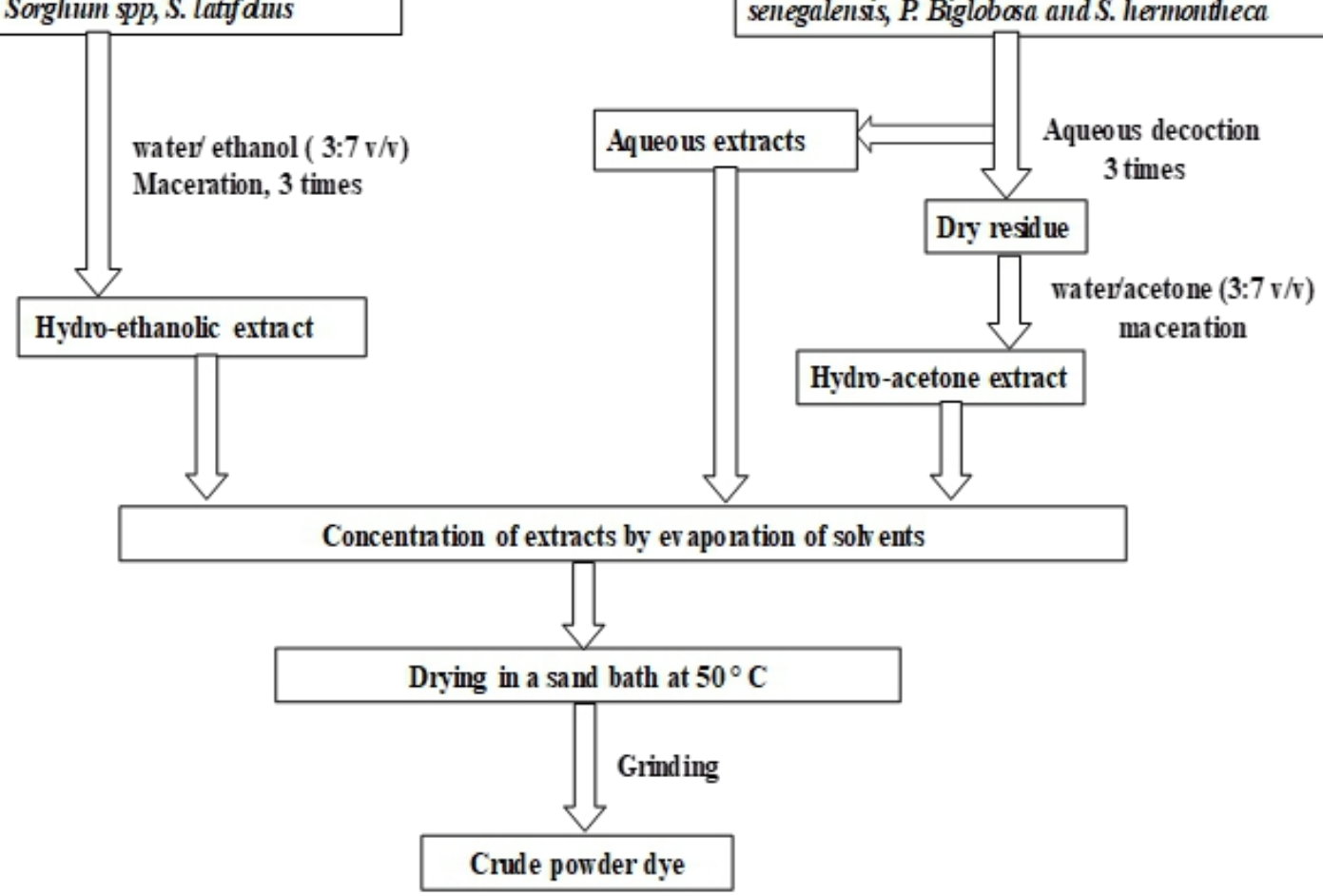

Figure 1. Extraction process

\section{Quantitative Estimation of Pigments of Photovoltaic Interest}

In order to evaluate the content of the main phenolic dyes present in the extracts, a spectrophotometric assay of the total polyphenols, flavonoids, anthocyanins, and tannins was carried out. The main reason for the choice of these substances lies in the fact that the dyeing properties of plants are attributed to the phenolic compounds (Kallo et al., 2018).

\section{Determination of Total Polyphenols}

The determination of total polyphenols is based on the ability of the Folin-Ciocalteu reagent to oxidize all the phenolic compounds. This reagent was reduced, during the oxidation of phenols, in a mixture of blue tungsten oxides $\left(\mathrm{W}_{8} \mathrm{O}_{23}\right)$ and of molybdenum $\left(\mathrm{Mo}_{8} \mathrm{O}_{23}\right)$. Then a blue color is produced and a maximum absorption is measured around $760 \mathrm{~nm}$ wavelength. It is proportional to the level of phenolic compounds. To $1 \mathrm{~mL}$ of extract, $5 \mathrm{~mL}$ of Folin-Ciocalteu reagent diluted 10 times and $4 \mathrm{~mL}$ of sodium carbonate $\left(\mathrm{Na}_{2} \mathrm{CO}_{3}, 75 \mathrm{gL}^{-1}\right)$ solution were added successively. The whole was left for 30 minutes before reading the absorbance with the spectrophometer at $760 \mathrm{~nm}$ (Ouattara et al., 2011; Siddiqui et al., 2017). The concentration of total 
polyphenols is expressed in milligrams of gallic acid equivalent per gram of dry vegetable matter in reference to the obtained calibration curve $\mathrm{y}=0.0133 \mathrm{x}$ $+0.0514, \mathrm{R}^{2}=0.9974$.

\section{Determination of Total Flavonoids}

Total flavonoids were determined by the aluminum trichloride method. Quercetin has been used as a standard. Thus, $1 \mathrm{~mL}$ of each sample and standard (prepared in methanol) is added to $1 \mathrm{~mL}$ of the $2 \% \mathrm{AlCl}_{3}$ solution (Ouattara et al., 2011; Siddiqui et al., 2017). After 10 minutes, the absorbance signal was measured at $\lambda \max =430 \mathrm{~nm}$. The concentration of total flavonoids is expressed in milligrams equivalent of quercetin per gram of dry matter in reference to the obtained calibration curve $y=0.4583 x+0.0473 ; \mathrm{R}^{2}=0.9993$.

\section{Determination of Total Anthocyanins}

The free anthocyanins and the combined anthocyanins were determined by the action of sodium bisulfite $\left(\mathrm{NaHSO}_{3}\right)$, a reagent with power to decolorize anthocyanins (Michel, 2012). Thus, $5 \mathrm{~mL}$ of extract are placed in two test tubes. In one of the tubes (control tube), $2 \mathrm{~mL}$ of distilled water were added and in the other, where the discoloration of anthocyanins is observed, $2 \mathrm{~mL}$ of sodium bisulfite solution were added. After 20 minutes, the absorbances of the two solutions are read via spectrophotometry at the wavelength of $520 \mathrm{~nm}$. The total anthocyanin concentrations of the various extracts expressed in $\mathrm{mgL}^{-1}$ are established using the following formula (Michel, 2012):

$$
[\text { Anthocyanin }]_{\text {Total }}=875 *\left(\text { Abs }_{\text {control tube }}-\text { Abs }_{\text {bisulfite tube }}\right)
$$

\section{Determination of Total Tannins}

Plant tannins are phenolic compounds soluble in water and having molecular weights between 500 and 3000 (Sereme et al., 2008, 2010). This assay is based on the property of proanthocyanidines to be transformed, by cleavage of the interflavane bond in acid medium and hot $\left(100^{\circ} \mathrm{C}\right)$, into colored anthocyanidins (yellow-green) absorbing mainly at $550 \mathrm{~nm}$ (Julien, 2012). For this, $2 \mathrm{~mL}$ of extract are placed in a hydrolysis tube with $1 \mathrm{~mL}$ of distilled water and $3 \mathrm{~mL}$ of concentrated hydrochloric acid $(12 \mathrm{~N}$ or $37 \%)$. The tube is then closed and placed in a water bath at $100^{\circ} \mathrm{C}$ for $30 \mathrm{~min}$. In parallel, a control tube containing the same solution is left at room temperature. After cooling the hydrolyzed tube, $0.5 \mathrm{~mL}$ of ethanol is added to each tube and the optical density is read at $550 \mathrm{~nm}$. The concentration is then calculated in $\mathrm{mgL}^{-}$ ${ }^{1}$ as shown in the following formula (Michel, 2012):

$$
[\text { Tannins }]_{\text {Total }}=19.33 *\left(\text { Abs }_{\text {hydrolyzed tube }}-A b s_{\text {control tube }}\right)
$$




\section{UV-Vis Spectrophotometric Characterization}

The coloring powders were thoroughly dissolved in methanol or acetone and filtered three times using Wattman paper. The limpid extracts obtained were then characterized by UV-Visible spectrophotometry. The spectra obtained were compared with the incident solar spectrum in order to evaluate the efficiency of the light collection of the main pigments.

\section{Results}

\section{Extraction Yield}

The extraction yield obtained is shown in Figure 2. It varied between 9.88 and $28.64 \%$ from one sample to another. The largest of approximately $28.64 \%$ was obtained with Lannea microcarpa extract followed by that of Anogeissus leiocarpus (27.53\%). The extract of Sarcocephalus latifolius contains the lowest value of the order of $9.88 \%$.

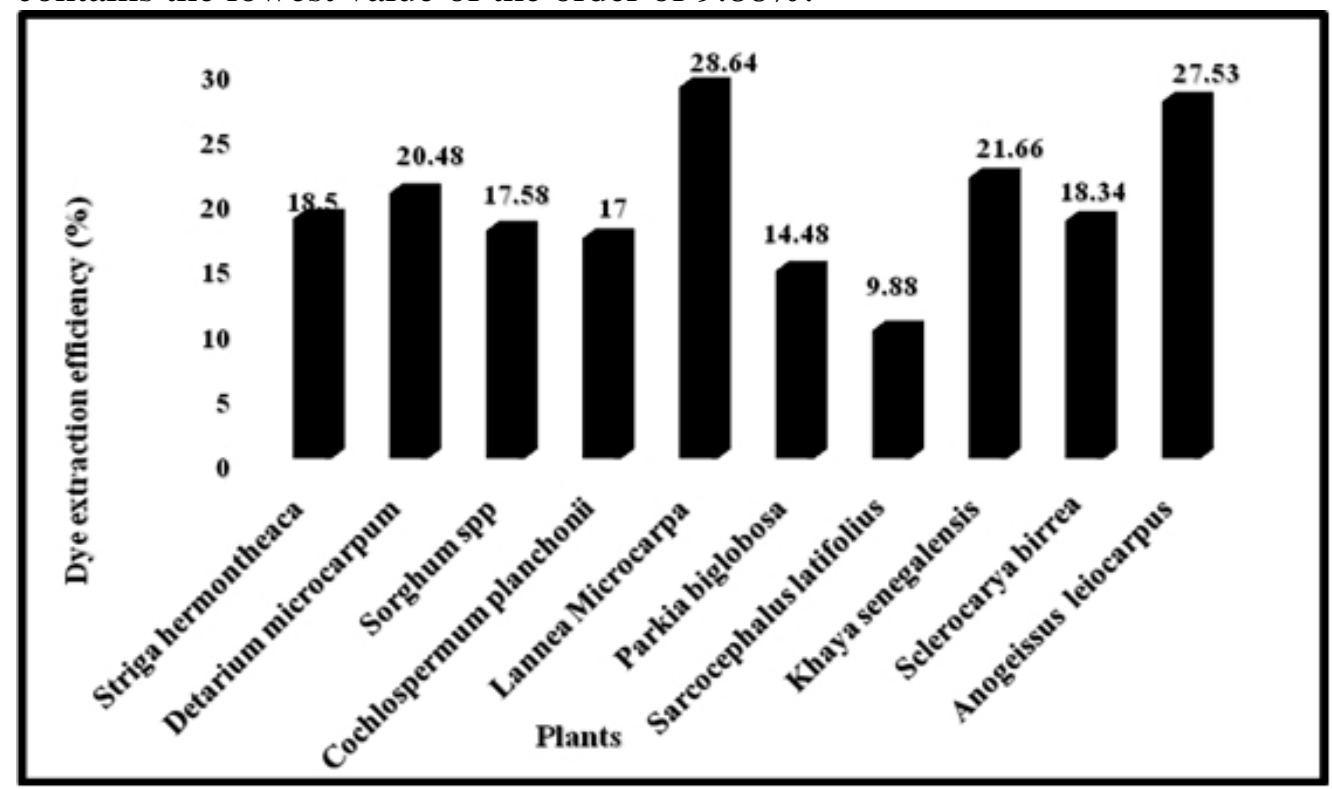

Figure 2. Extraction yield of different plants

\section{Determination of Compounds of Photovoltaic Interest}

The quantitative study of the crude extracts, prepared from the different organs of plant species, using spectrophotometric method was aimed to determine the content of the main total polyphenols. The concentrations of the total polyphenols are obtained from calibration curves established using standard gallic acid. These contents are shown in Table 1 and it ranges from 28.93 to $46.54 \mathrm{mg}$ gallic acid equivalent per gram of dry crude extract powder (mg EqAG/g). This result shows that all the studied plants contain polyphenols at high concentration. The most important are observed in the extract of sheaths of sorghum spp, in the leaves of Anogeissus leiocarpus, and in the bark 
of Lannea microcarpa, Sclerocarya birrea, Khaya senegalensis, Detarium microcarpum, and Parkia biglobosa. The flavonoid contents obtained (Table 1) vary from 1.56 to $10.95 \mathrm{mg}$ quercetin equivalent per gram of dry matter (mgEqQuer/g). The highest levels are obtained in extracts of Striga hermontheca and Sorghum spp with 10.95 and $10.62 \mathrm{mgEqQuer} / \mathrm{g}$ respectively. However, the contents present in the rest of plants are interesting compared to the relatively high cost of synthesis of the same types of molecules industrially. The tannin contents obtained are shown in Table 1. These contents vary from 0.8 to $40.1 \mathrm{mgL}^{-1}$. The highest concentrations are observed in the bark of the trunk of the species. These species are interesting for the commercial exploitation of tannins. They would be a potential source of material for large-scale production of tannins. The anthocyanin contents in the extracts of the species studied are presented in Table 1. These contents vary from 0.8 to $181.9 \mathrm{mgL}^{-1}$. The highest concentrations are observed in the extract of sheath Sorghum spp, Striga hermontheca, bark of the trunk Lannea microcarpa, Detarium microcarpum, Parkia biglobosa, Sclerocarya birrea species. These species are interesting because of their abundance and availability for the production of anthocyanins. They would then constitute potential sources of material for the large-scale production of low-cost plant origin anthocyanins.

Table 1. Content of phenolic compounds present in plant extracts studied.

\begin{tabular}{|c|c|c|c|c|}
\hline Plants samples & $\begin{array}{l}\text { Total polyphenols } \\
\left(\mathrm{mg} \mathrm{EqAGg}^{-1}\right)\end{array}$ & $\begin{array}{l}\text { Total flavonoids } \\
\left(\mathrm{mg} \mathrm{EqQuerg}^{-1}\right)\end{array}$ & $\begin{array}{l}\text { Total tannins } \\
\left(\mathrm{mgL}^{-1}\right)\end{array}$ & $\begin{array}{ll}\text { Total } \\
\left(\mathrm{mgL}^{-1}\right)\end{array}$ anthocyanins \\
\hline A leiocarpus & $39.13 \pm 0.71$ & $3.68 \pm 0.07$ & $2.86 \pm 0.04$ & $9.62 \pm 0.04$ \\
\hline Cplanchonii & $36.61 \pm 0.69$ & $3.96 \pm 0.06$ & $0.80 \pm 0.01$ & $2.25 \pm 0.02$ \\
\hline D microcarpum & $37.17 \pm 1.14$ & $3.29 \pm 0.02$ & $27.58 \pm 0.12$ & $122.50 \pm 1.86$ \\
\hline K senegalensis & $37.03 \pm 0.18$ & $1.56 \pm 0.04$ & $40.10 \pm 0.09$ & 19.250.15 \\
\hline L microcarpa & $36.61 \pm 0.40$ & $3.12 \pm 0.02$ & $24.43 \pm 0.13$ & $70.87 \pm 0.14$ \\
\hline P biglobosa & $38.29 \pm 0.26$ & $6.90 \pm 0.04$ & $19.00 \pm 0.06$ & $67.37 \pm 0.54$ \\
\hline$S$ birrea & $38.71 \pm 0.15$ & $3.42 \pm 0.02$ & $13.76 \pm 0.06$ & $14.87 \pm 0.54$ \\
\hline S hermontheca & $28.93 \pm 0.24$ & $10.96 \pm 0.04$ & $3.55 \pm 0.05$ & $110.25 \pm 0.63$ \\
\hline S latifolius & $35.91 \pm 0.24$ & $2.16 \pm 0.01$ & $2.24 \pm 0.02$ & $0.87 \pm 0.05$ \\
\hline Sorghum spp & $46.54 \pm 0.17$ & $10.63 \pm 0.10$ & $1.90 \pm 0.03$ & $181.90 \pm 0.69$ \\
\hline
\end{tabular}

\section{Spectrophotometric Characterization of Pigments}

UV-visible spectrophotometry is widely used to obtain important information that helps to know and identify chemical compounds. Thus, the spectra of extracts of Parkia biglobosa, Detarium microcarpum, Sclerocarya birrea, Khaya senegalensis and Lannea microcarpa all show intense UV absorptions with peaks around $280 \mathrm{~nm}$, and also low visible absorptions between 400 and $500 \mathrm{~nm}$. For spectra of extracts of Cochlospermum planchonii and Sarcocephalus latifolia (Figure $3 \mathrm{f}$ and 3g), intense absorption bands were observed in the visible range. The absorption of Cochlospermum 
planchonii was observed between 380 and $500 \mathrm{~nm}$ with an absorption maximum at $434 \mathrm{~nm}$ which is coupled with minor peaks located at $410 \mathrm{~nm}$ respectively at $457 \mathrm{~nm}$. For extracts of Striga hermontheca and Anogeissus leiocarpus (Figures $3 \mathrm{~h}$ and 3i), absorption bands in the visible were observed. For the extract of Striga hermontheca, the maximum absorption is in blue at $410 \mathrm{~nm}$ and in red at $664 \mathrm{~nm}$. The extract absorption of Anogeissus leiocarpus shows intense peaks at 370,410 , and $664 \mathrm{~nm}$. The absorption spectrum of the sorghum spp extract shows two main characteristic absorption bands (Figure $3 \mathrm{j})$ : the absorption around $270-280 \mathrm{~nm}$ and that between $450-550 \mathrm{~nm}$. The maximum absorption is observed in the visible domain around $490 \mathrm{~nm}$. A little absorption band is observed between 320 and $360 \mathrm{~nm}$. 


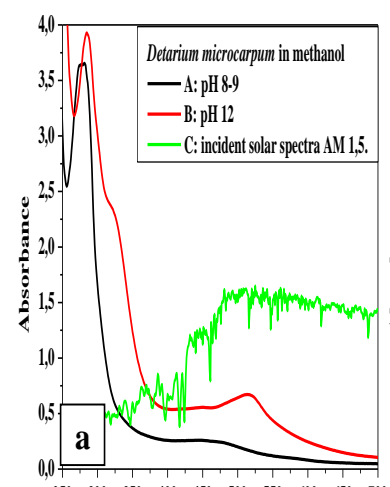

$250 \quad 300 \quad 350400 \quad 450 \quad 500 \quad 550600650 \quad 70$ wavelength $(\mathrm{nm})$

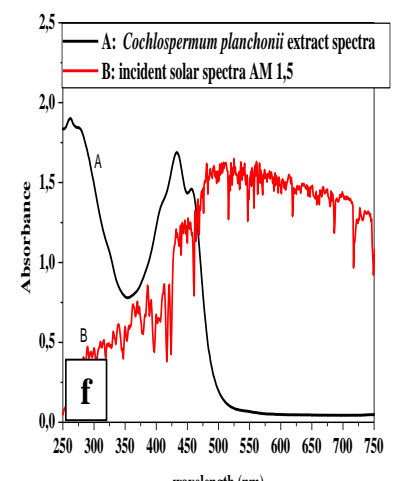

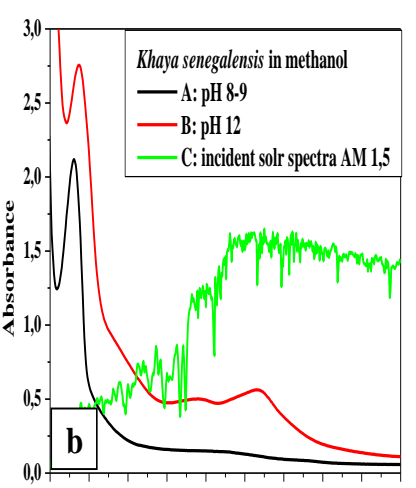

wavelength $(\mathrm{nm})$

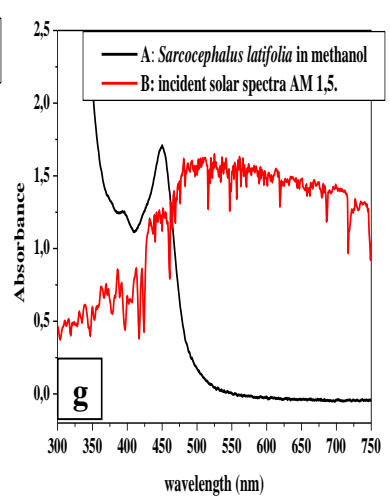

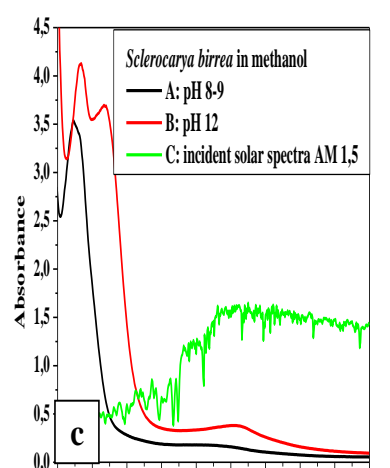

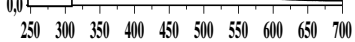
wavelength $(\mathrm{nm})$

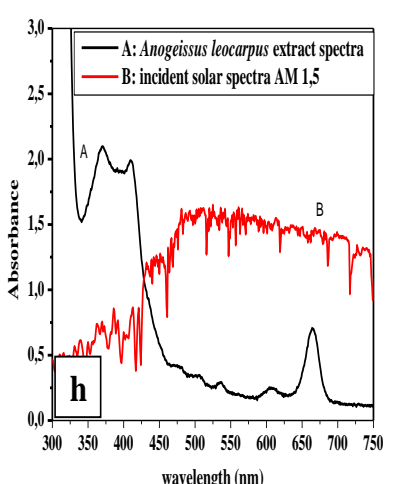

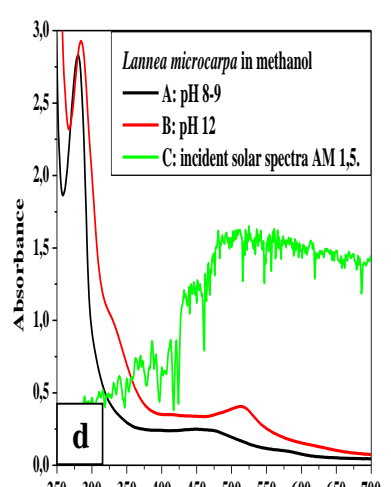

wavelength $(\mathrm{nm})$

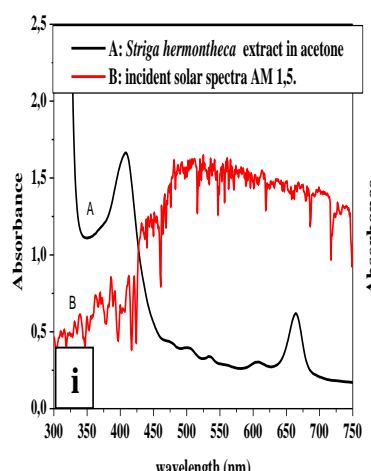

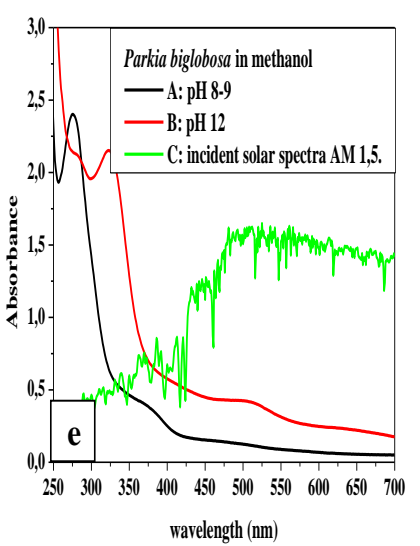

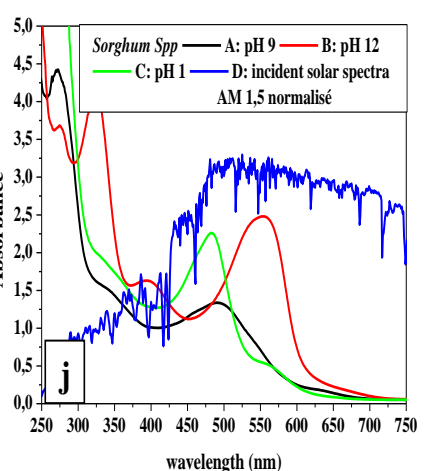

Figure 3. UV-Visible spectrum of extracts of: (a) Detarium microcarpum; (b) Khaya senegalensis; (c) Lannea microcarpa; (d) Sclerocarya birrea; (e) Parkia biglobosa; $(f)$ Cochlospermum planchonii; $(g)$ of Sarcocephalus latifolia; $(h)$ Anogeissus leocarpus; ( $i$ ) Striga hermontheca; and $(j)$ sorghum spp. 


\section{Discussion}

The extraction yields obtained are significantly important in Detarium microcarpum, Khaya senegalensis, Lannea microcarpa, Sclerocarya birrea, Parkia biglobosa, Cochlospermum planchonii, Sarcocephalus latifolia, Anogeissus leiocarpus, Striga hermontheca, and Sorghum spp crude extracts. The height content could be due not only to the composition of the plant species sample, but also to the physicochemical properties and affinities of the solvents with extractable substances (Mahmoudi et al., 2013). These results show that the studied plants are interesting sources of raw materials for the production of natural dyes of plant origin. This height contents can give possibility to be used in several fields (Harouna et al., 2012; Mabika et al., 2013) and in solar energy especially in the new photovoltaic technologies (Dye Sensitized-Solar Cells).

Spectrophotometric determination of the compounds of photovoltaic interest such as total polyphenols, total flavonoids, total anthocyanins, and total tannins showed that these plants are rich in dyes. The high contents of total polyphenols (30-40 mgEqAG / g) could give the hope of finding various pigments belonging to different class families. However, these high contents may result because the Folin Ciocalteu reagent is not specific to polyphenols, but many compounds may react with this reagent, resulting in a high apparent phenol content (Tawaha et al., 2007). The total tannin contents obtained reveal that the barks of Detarium microcarpum, Khaya senegalensis, Lannea microcarpa, Sclerocarya birrea, Parkia biglobosa have high tannin concentrations comparable to those of allochthones species long used for large-scale tannin exploitation (Sereme et al., 2008). The anthocyanin levels of the plants are promising. Indeed, anthocyanins are used in various fields, particularly in the production of various colors, in the therapeutic field, and in the food industry. Recently in the field of solar energy, especially in dye sensitized-solar cells (Calogero et al., 2012; Saha et al., 2016), natural dyes have been the subject of intense investigation. Anthocyanins constituted one of the most indexed colored compounds when searching for effective photosensitive pigments. Their presence at high levels in these plant species gives hope in the search for the miracle pigment capable most effectively of converting sunlight into electricity.

UV-Visible spectrophotometry is now very much in demand to evaluate the efficiency of collecting sunlight from pigments in photovoltaic cells. The UV-Vis absorption spectra of the crude extracts shown in Figure 3 are compared to that of solar radiation incident on the earth which normally diffuses $5 \%$ of ultraviolet, $43 \%$ of visible light, and $52 \%$ of infrared (Grätzel, 2003; Grätzel, 2004; Kalyanasundaram, 2010). However, sunlight will provide the highest visible light spectrum (54\%) at the time of air mass (AM) 1.5 (McConnell \& Brudvig, 2010). The Detarium microcarpum, Khaya 
senegalensis, Lannea microcarpa, Sclerocarya birrea, and Parkia biglobosa extracts spectra all have absorptions around $280 \mathrm{~nm}$, characteristic of phenolic compounds. This could be attributed to the phenolic group of anthocyanin, tannin, and flavonoids present in the extracts of these plants (Gajula \& Rayani, 2012; Agbangnan et al., 2013; Kallo et al., 2018). This spectrum information seems to confirm the results of the phytochemical screening carried out on these species where these same compounds have been detected (Cardon et al., 2010; Kallo et al., 2018). Moreover, as indicated by certain dyeing preparations (Cardon et al., 2010), the extracts of these five plant species were treated in a basic medium at $\mathrm{pH}=12$, which makes it possible to observe a more colored appearance of the extracts (in intense red). This change in the color of the solution in basic medium would be caused by the activation, the release or the formation of certain organic functions or chromophoric functions and /or the change from the phenolic form to the phenolate form of the phenolic compounds found very frequently in extracts (Kallo et al., 2018). This results in a displacement towards the long wavelength (bathochromic effect) of the UV and visible absorption bands and an increase in the intensity of absorption between 450 and $550 \mathrm{~nm}$ (red spectrum of Figure 3a, 3b, 3c, 3d and $3 \mathrm{e})$. Thus, in the visible zone and in basic medium, the spectrum of the extract of Detarium microcarpum has a remarkable peak at $514 \mathrm{~nm}$, that of Khaya senegalensis two peaks at 440 and $517 \mathrm{~nm}$, that of Lannea microcarpa a peak at $515 \mathrm{~nm}$, that of Sclerocarya birrea a peak at $505 \mathrm{~nm}$, and that of Parkia biglobosa a peak at $510 \mathrm{~nm}$ (red spectra of Figures 3a, 3b, 3c, 3d and $3 e)$. These absorptions would be attributed to $\pi-\pi *$ and $n-\pi *$ transitions of chromophores present in the anthocyanin, flavonoid, and tannoids pigments.

In addition, the photovoltaic efficiency of the pigments depends partly not only on their visible absorption, but also on their adhesion with the semiconductor nanoparticles used (Basheer et al., 2014). Thus, the more the pigment absorbs a large part of the solar spectrum, the more it collects solar radiation and the more it is efficient to convert sunlight into electricity. It is for this reason that the incident solar spectrum is represented in order to evaluate the collection efficiency of the solar light of the pigments with respect to the latter. In addition to the visible absorption 400 and $700 \mathrm{~nm}$, these pigments also have hydroxide groups allowing them to be well adsorbed on the semiconductor particles. This property could make pigments good candidates to ensure a good injection of electrons into the titanium dioxide $\left(\mathrm{TiO}_{2}\right)$ conduction band, which is widely used in dye sensitized-solar cells (Gong et al., 2012). This injection would be favored by the position of the pigment's frontal orbital with respect to the semiconductor conduction bands in the energy diagram (Hagfeldt et al., 2010; Lim et al., 2015).

For the Cochlospermum planchonii extract, the absorption spectrum has similarities to that of crocetin (peaks at 414, 436 and $463 \mathrm{~nm}$ ) and crocin 
(peaks at 421, 442 and $471 \mathrm{~nm}$ ), which are carotenoid pigments (Yamazaki et al., 2007). In addition, Ekanayake et al. (2012) studied the absorption of lutein, another carotenoid pigment, and they observed the absorption peaks at 404, 423, and $471 \mathrm{~nm}$. Comparison of the absorptions of crocetin, crocin, lutein Cochlospermum planchonii pigments suggests that the Cochlospermum planchonii extract would contain compounds belonging to the carotenoid family. In addition, the absorption of carotenoid pigments would be attributed to $\pi-\pi *$ transitions of $-\mathrm{C}=\mathrm{C}$-conjugated chromophores in an isoprene chain and $n-\pi *$ transitions due to the presence of a few hydroxyl groups in these pigments.

The absorption of Sarcocephalus latifolia root extract is at $450 \mathrm{~nm}$. These absorptions would be attributed to $\pi-\pi *$ transitions of $-\mathrm{C}=\mathrm{C}-$ and $-\mathrm{C}=$ $\mathrm{N}$ - and / or $-\mathrm{N}=\mathrm{N}$ - chromophores present in this reputed nitrogen-compound (Badiaga, 2012). This seems to confirm the results of the phytochemical screening that shows the presence of compounds such as alkaloids and polyterpenes in the extract (Badiaga, 2012; Kallo et al., 2018). Thus, the presence of anchor groups (-OH, $-\mathrm{NH}-)$ in these pigments could promote good adsorption on the semiconductor particles and easier electron injection into the $\mathrm{TiO}_{2}$ band gap and would give these last a sensitizing photo activity.

The similar absorption characteristics of Striga hermontheca and Anogeissus leiocarpus have been reported by many authors to correspond to chlorophyll compounds (Ewa, 2009; Calogero et al., 2009; McConnell \& Brudvig, 2010). In addition, Calogero et al. (2009) showed that these two absorption bands could be attributed to the $\pi-\pi *$ transitions, notably the weaker $Q$ band at longer wavelengths $(550-700 \mathrm{~nm})$ and the intense sorbet band in the visible region near $(400-450 \mathrm{~nm})$. In addition, these two pigments have interesting absorption characteristics because they absorb the blue and red regions of the solar spectrum. The efficiency of solar radiation collection will then depend on the absorption of the blue photon or that of the red photon. This property would favor the collection of solar radiation and the electron injection in the semiconductor conduction band through the pigment lowest unoccupied molecular orbital in energy (LUMO), populated after the solar radiation absorption processes.

Absorption of sorghum spp extract appears to be more promising in terms of sunlight collection. The absorption around 270-280 nm could be attributed to the phenolic group and that between $450-550 \mathrm{~nm}$ would be linked to the pyrylium nucleus and the conjugation of the two benzene rings (Agbangnan et al., 2013; Lim et al., 2015). According to Agbangnan et al. (2013), the not very remarkable absorption band between 320-360 nm would indicate the presence of aromatic acid residue in these known anthocyanin compounds. The visible absorption band could be attributed to a charge transfer transition $\pi-\pi *$ which results in a shift of the electron charge density 
from the chromenium portion to the catechol end of the molecule. The absorption band of anthocyanins is sensitive to $\mathrm{pH}$ and solvents (Lim et al., 2015). The influence of $\mathrm{pH}$ on the absorption of pigments to evaluate the stability and dye properties of the pigment was investigated using concentrated solutions of sodium hydroxide and hydrochloric acid. Indeed, with the addition of a few drops of acid, the appearance of sorghum spp extract in methanol (orange-black color) has turned to orange showing the form of flavylium ion in this acid medium (Lim et al., 2015). This shows a hyperchromic effect of the absorption of the pigment. In addition, the treatment of the methanolic extract with sodium hydroxide solution turns the solution to purplish pink, thus showing the passage of anthocyanin compounds towards the deprotonated quinonoidal form (Lim et al., 2015). Thus, the spectrum resulting from the pink-violet solution compared to that recorded in methanol makes it possible to observe a bathochromic and hyperchromic effects on absorption. Moreover, as it can be seen from Figure 3j, the pigment extracted from sorghum has a broad and intense absorption in the visible range between 400 and $800 \mathrm{~nm}$ (especially in basic medium). This important absorption could make this pigment an effective sensitizing potential dye to collect solar radiation and their conversion into electricity.

\section{Conclusion}

This study allowed us to extract in an optimized way the various polyphenolic pigments present in ten species of dyeing plants of Niger. These plants have proved very interesting potentials considering their dye extraction yields that vary from about 10 to $28 \%$. Otherwise, the high contents obtained by spectrophotometric determination of anthocyanins, flavonoids, tannins, and total polyphenols make these plants potential sources for the production of natural dyes of plant origin. The absorption spectra of these dyes show intense absorption domains in the near ultra-violet $(320-400 \mathrm{~nm})$ and the visible $(400-700 \mathrm{~nm})$ which matches the most important solar radiation spectrum on earth. The spectrophotochemical properties of studied plants pigments make them potential sensitizers that can be exploited in solar energy, particularly in dye sensitized-solar cells.

\section{Acknowledgements}

My sincere thanks go to the German Federal Ministry of Education and Research (BMBF) and the West Africa Science Center on Climate Change and Adapted Land Use (WASCAL) for their partial fellowship. 


\section{References:}

1. Abrams, N.M. (2005). Efficiency enhancement in dye sensitized solar cells through light manipulation. PhD thesis in Chemistry, Pennsylvania State University PhD, pp:1.

2. Agbangnan, D.C.P., Noudogbessi, A., Chrostowska, J.P., Tachon, C., Fouquet, E., \& Sohounhloue, D.C.K. (2008). Phenolic compound of benin's red sorghum and their antioxidant properties, Asian J Pharm Clin Res, Vol 6, Suppl 2, 280-283.

3. Asim Nilofar, Kamaruzzaman Sopian, Shideh Ahmadi, Kasra Saeedfar, M. A. Alghoul, Omidreza Saadatian, \& Saleem H. Zaidi. (2012a). "A Review on the Role of Materials Science in Solar Cells." Renewable and Sustainable Energy Reviews 16 (8): 5834-47. https://doi.org/10.1016/j.rser.2012.06.004.

4. Badiaga Mamadou (2012). Etude ethnobotanique, phytochimique et activites biologiques de Nauclea latifolia Smith, une plante médicinale africaine récoltée au Mali. Other. Université Blaise Pascal - ClermontFerrand II, 2011. French. <NNT : 2011CLF22187>. <tel-0071956.

5. Basheer Bismi, Dona Mathew, Benny K George, \& C P Reghunadhan Nair (2014). "ScienceDirect An Overview on the Spectrum of Sensitizers : The Heart of Dye Sensitized Solar Cells." Solar Energy 108. Elsevier Ltd: 479-507. https://doi.org/10.1016/j.solener.2014.08.002.

6. Bolton J.R. (ed.) (1977). Solar powers and fuels, academic Press: New York.

7. Blankenship, R. (2008). Molecular mechanism of photosynthesis, John Wiley \& Son Inc.

8. Calogero, Giuseppe, Di Marco, Stefano Caramori, Silvia Cazzanti, \& Carlo Alberto (2009). "Natural Dye Senstizers for Photoelectrochemical Cells," 1162-72. https://doi.org/10.1039/b913248c.

9. Calogero, Giuseppe, Jun Ho Yum, Alessandro Sinopoli, Gaetano Di Marco, Michael Grätzel, \& Mohammad Khaja Nazeeruddin (2012). "Anthocyanins and Betalains as Light-Harvesting Pigments for DyeSensitized Solar Cells." Solar Energy 86 (5): 1563-75. https://doi.org/10.1016/j.solener.2012.02.018.

10. Cardon Dominique. n.d. "“ Cultures de Couleurs: Découverte , Gestion, Perspectives Des Colorants Naturels' Teintures Naturelles : Applications Textiles."

11. Ekanayake, Piyasiri, Mohammad Iskandar, Kushan Tennakoon, \& Lim Chee Ming (2012). "Fabrication of Eco-Friendly Dye Sensitized Solar Cells Using Pigments from Melastoma Malabathricum L ., a Native Plant in Borneo." Ceylon Journal of Science (Physical 
Sciences) 16: 65-70.

12. Gajula Chinna Devi \& Bhaskara R A O Rayani (2012). “Academic Sciences" 5 (1): 3-6.

13. Gong, J., Jing, L., \& Sumathy, K. (2012). "Review on Dye-Sensitized Solar Cells (DSSCs ): Fundamental Concepts and Novel Materials." Renewable and Sustainable Energy Reviews 16 (8). Elsevier: 584860. https://doi.org/10.1016/j.rser.2012.04.044.

14. Grätzel, M. (2003). "Dye-Sensitized Solar Cells" 4: 145-53. https://doi.org/10.1016/S1389-5567(03)00026-1.

15. Grätzel Michael (2004). Conversion of Sunlight to Electric Power by Nanocrystalline Dye-Sensitized Solar Cells 164: 3-14. https://doi.org/10.1016/j.jphotochem.2004.02.023.

16. Harouna, Sore, Hilou Adama, Sombie Pierre, Alexandre Eric, Compaore Moussa, \& Nacoulma Odile Germaine (2012). "Open Access Review Article Dyeing and Medicinal Plants Used in the Area of Mouhoun in Burkina Faso Abstract: Introduction : Materials and Methods : Study Area: Method of Data Collection : Identification and Establishment of Voucher Specimens : Results a" 2 (3): 110-18.

17. Hagfeldt, A., Boschloo, G., Sun, L., Kloo, L., \& Pettersson, H. (2010). Dye-sensitized solar cells. Chemical reviews, 110(11), 6595-6663.

18. Hug, Hubert, Michael Bader, Peter Mair, \& Thilo Glatzel (2014). "Biophotovoltaics : Natural Pigments in Dye-Sensitized Solar Cells." Applied Energy 115. Elsevier Ltd: 216-25. https://doi.org/10.1016/j.apenergy.2013.10.055.

19. Kallo, M. S., Adamou, R., Sawadogo, J., Mahamane, A. A., Maarouhi, I. M., \& Ikhiri, K. (2018). Enquête ethnobotanique et criblage phytochimique de quelques plantes tinctoriales du Niger en vue d'une valorisation en énergie solaire. International Journal of Biological and Chemical Sciences, 12(2), 867-883.

20. Kalyanasundaram K., (ed.) (2010). Dye-sensitized solar cells. Presses polytechniques et universitaires romandes, EPFL press, 2010, Photochemical and photoelectrochemical approaches to energy conversion, $p p: 1-43$.

21. Lim, A., Kumara, N. T. R. N., Tan, A. L., Mirza, A. H., Chandrakanthi, R. L. N., Petra, M. I., ... \& Ekanayake, P. (2015). Potential natural sensitizers extracted from the skin of Canarium odontophyllum fruits for dye-sensitized solar cells. Spectrochimica Acta Part A: Molecular and Biomolecular Spectroscopy, 138, 596-602.

22. Mabika, A B., Madiélé, C., Nkounkou, L., Agnaniet, H., Moutsamboté, J M., \& Ouamba, JM. (2013). "Les Plantes Tinctoriales D ' Afrique Centrale: Enquête Ethnobotanique et Screening Phytochimique," 5236-51. 
23. McConnell, Iain, Gonghu Li, \& Gary W. Brudvig (2010). "Energy Conversion in Natural and Artificial Photosynthesis." Chemistry and Biology $\quad 17 \quad$ (5). Elsevier $\quad$ Ltd: 434-47. https://doi.org/10.1016/j.chembiol.2010.05.005.

24. Mehmood, Umer, Saleem-ur Rahman, Khalil Harrabi, Ibnelwaleed A Hussein, \& B V S Reddy (2014). "Recent Advances in Dye Sensitized Solar Cells" 2014.

25. Michel, J. (2012). Classification et influences des polyphénols du bois de chêne sur la qualité sensorielle des vins (Application du procédé OakScan®) (Doctoral dissertation, Bordeaux 2).

26. Millogo-Kone, H., Guissou, I P., Nacoulma, O., \& Traore, A S. (2008). "Comparative Study of Leaf and Stem Bark Extracts of Parkia Biglobosa against Enterobacteria. ." African Journal of Traditional, Complementary and Alternative Medicines 5 (3): 238-43. http://journals.sfu.ca/africanem/index.php/ajtcam/article/view/418.

27. O’Regan, Brian, \& Michael Grätzel. (1991). "A Low-Cost, HighEfficiency Solar Cell Based on Dye-Sensitized Colloidal TiO2 Films." Nature 353 (6346): 737-40. https://doi.org/10.1038/353737a0.

28. Ouattara, L., Koudou, J., Zongo, C., Barro, N., Savadogo, A., Bassole, I.H.N., Ouattara, A. S. \& Alfred, S. Traore (2011). “Antioxidant and Antibacterial Activities of Three Species of Lannea from Burkina Faso." Journal of Applied Sciences 11 (1): 157-62. https://doi.org/10.3923/jas.2011.157.162.

29. Rabinowitch \& Govindjee (1969). Photosynthesis, London: J. Willey.

30. Saha, Saptadip, Priyanath Das, Ajoy Kumar Chakraborty, Sharmistha Sarkar, \& Ruchira Debbarma (2016). "Fabrication of DSSC with NanoporousTiO 2 Film and Kenaf Hibiscus Dye as Sensitizer." International Journal of Renewable Energy Research 6 (2): 620-27.

31. Sereme, A.J., Millogo-Rasolodimby, S., Guinko, \& Nacro, M. (2010). "Anatomie Et Concentration Des Tanins Des Plantes Tanniferes Du Burkina Faso." Journal Des Sciences 10 (2): 24-32.

32. Siddiqui, Nazish, Abdur Rauf, Abdul Latif, \& Zeenat Mahmood (2017). "Spectrophotometric Determination of the Total Phenolic Content, Spectral and Fluorescence Study of the Herbal Unani Drug Gul-E-Zoofa (Nepeta Bracteata Benth)." Journal of Taibah University Medical Sciences 12 (4). Elsevier Ltd: 360-63. https://doi.org/10.1016/j.jtumed.2016.11.006.

33. Siva, R. (2014). "Status of Natural Dyes and Dye-Yielding Plants in India Status of Natural Dyes and Dye-Yielding Plants in India," no. April 2007: 1-10.

34. Tawaha, Khaled, Feras Q. Alali, Mohammad Gharaibeh, Mohammad Mohammad, \& Tamam El-Elimat (2007). "Antioxidant Activity and 
Total Phenolic Content of Selected Jordanian Plant Species." Food Chemistry 104 (4):

1372-78. https://doi.org/10.1016/j.foodchem.2007.01.064.

35. Yamazaki, Eiji, Masaki Murayama, Naomi Nishikawa, Noritsugu Hashimoto, Masashi Shoyama, \& Osamu Kurita (2007). "Utilization of Natural Carotenoids as Photosensitizers for Dye-Sensitized Solar Cells" 81: 512-16. https://doi.org/10.1016/j.solener.2006.08.003. 